\section{Scientific journal}

\section{PHYSICAL AND MATHEMATICAL EDUCATION}

Has been issued since 2013.

Науковий журнал

ФІЗИКО-МАТЕМАТИЧНА ОСВІТА

Видається з 2013.
ISSN 2413-158X (online)

ISSN 2413-1571 (print)

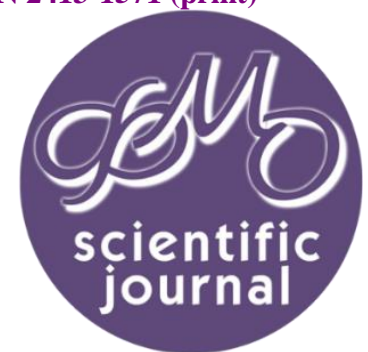

Гребеник А.О. Структура професійної компетентності майбутніх бакалаврів залізничного транспорту у фаховій підготовиі. Фізико-математична освіта. 2021. Випуск 2(28). С. 6-10.

Hrebenyk A. Professional competence structure of future bachelors of railway transport in professional training. Physical and Mathematical Education. 2021. Issue 2(28). P. 6-10.

DOI 10.31110/2413-1571-2021-028-2-001

UDC 378.046-021.64:656.2-051]:005.336.2-027.561

A. Hrebenyk

Oleksandr Dovzhenko Hluhiv National Pedagogical University, Ukraine polishlanguage1111@gmail.com ORCID: 0000-0002-3051-5713

\title{
PROFESSIONAL COMPETENCE STRUCTURE OF FUTURE BACHELORS OF RAILWAY TRANSPORT IN PROFESSIONAL TRAINING
}

\section{ABSTRACT}

Under intensive living and production conditions, questions increasingly arise not so much about the content of knowledge acquired by students, but about highly effective methods, forms, means of professional competence formation as the professional training important component. This article raises the issue of the professional competence formation of future railway transport specialists in the professional training. The scientific publications on the research topic are analyzed and the professional competence structural components of future bachelors' in this field are identified.

Formulation of the problem. Nowadays, more and more employers are not fully satisfied with the specialists' training. As a result, there is a significant reform of the educational sector. Special attention is paid to the issues of professional training. Thus, the professional competence formation of the future specialist is a relevant and important issue. And the question of the professional competence structure of future specialists, including future bachelors of railway transport, needs a detailed study.

Materials and methods. In the scientific process, dissertation research materials, pedagogical and scientific literature were used. To achieve the goal of the study theoretical and empirical methods: analysis and systematization; observation; written and oral interview; analysis, systematization, generalization were used.

Results. Thus, the professional competence components of future bachelors of railway transport are identified, namely: motivational-value, personal-functional, reflexive-evaluative.

Conclusions. The proposed professional competence structure of future bachelors of railway transport is singled out taking into account the professional competence content and these specialists' professional activity features. Structuring the category "professional competence of future bachelors of railway transport" can positively affect the organization level of this competence formation process in students in the training process and the process quality of its formation diagnosing level. Further research is needed on the model development of this process and its organizational and methodological support.

KEY WORDS: professional training, professional competence, components, bachelor of railway transport, professional.

\section{INTRODUCTION}

The problem formulation. At the present stage of democratic transformations the problem of professional competence formation of future bachelors of railway transport acquires special urgency, constant interest from the state in view of new public relations creation, other standards of working conditions introduction, etc. Creating a competitive professional is one of the goals of both employers and educational institutions. The new paradigm of education focuses on the professionally competent specialists' training, including in the field of railway transport. The educational process should be focused not on the information transfer, but on its understanding and ability to apply what was learned during the safe performance of professional practical tasks, on the components professional competence formation of future bachelors in the railway industry: motivational-value, personal-functional, reflexive-evaluative.

Research relevance. The concept of professional competence has been studied at different times by scientists (Gershunsky, 1998) defined professional competence as a level of professional education, (Pometun, 2005) - an objective category, (Dybkova, 2006) - the ability to effectively use the acquired knowledge, skills and abilities, (Yagupov, 2007) - system integral phenomenon, (Chaplak and Kotova, 2010) - a system that integrates knowledge, skills, abilities of various spheres of human life and professionally significant personality qualities, (Yevtushenko and Vitrenko, 2013) - personal opportunities that allow independently and effectively implement the goals of the management process, (Nizovtsev, 2013) - an integrative system 
of properties and qualities of personality, professional knowledge, skills, abilities, ability to perform professional activities at a high level, (Gorban, 2015) - a complex integrated psychological, professional and subjective education, which is formed in the process of acquiring professional education, updated, developed and improved in the process of practical professional activity, etc.

The professional competence structure in their research was considered by scientists (Zymnya, 2003) knowledge; skills and abilities, ability and readiness to use them in professional activities; confidence in activity and responsibility for its results), (Karpova, 2004): motivational and subject-practical sphere, sphere of self-regulation, (Yagupov, 2007): praxeological, motivational, cognitive, subjective components, (Vyshpolska, 2008): motivational-volitional communicative, reflective, semantic components), (Nizovtsev, 2013): value-motivational, personal, meaningful, activity, reflexive-evaluative, creative and innovative, (Gorban, 2015): value-motivational, cognitive, functional, communicative, reflexive-status, etc. However, despite the scientists' significant contribution in solving the problem, the question of the professional competence structure of future bachelors of railway transport has not been fully explored.

The aim of the article is determining the professional competence structure of future bachelors of railway transport and considering its components.

\section{RESEARCH METHODS}

To achieve this goal, the methods of theoretical research were used: systematic and comparative analysis of scientific publications on the research topic, our own experience self-analysis, systematization and generalization.

\section{RESULTS}

Based on the different approaches analysis to the characteristics of specialists' professional competence and applicants for higher education and the results of their own research, the semantic components of this socially significant quality of future bachelors of railway transport in professional training are highlight (see Fig. 1). In particular, these are the following components:

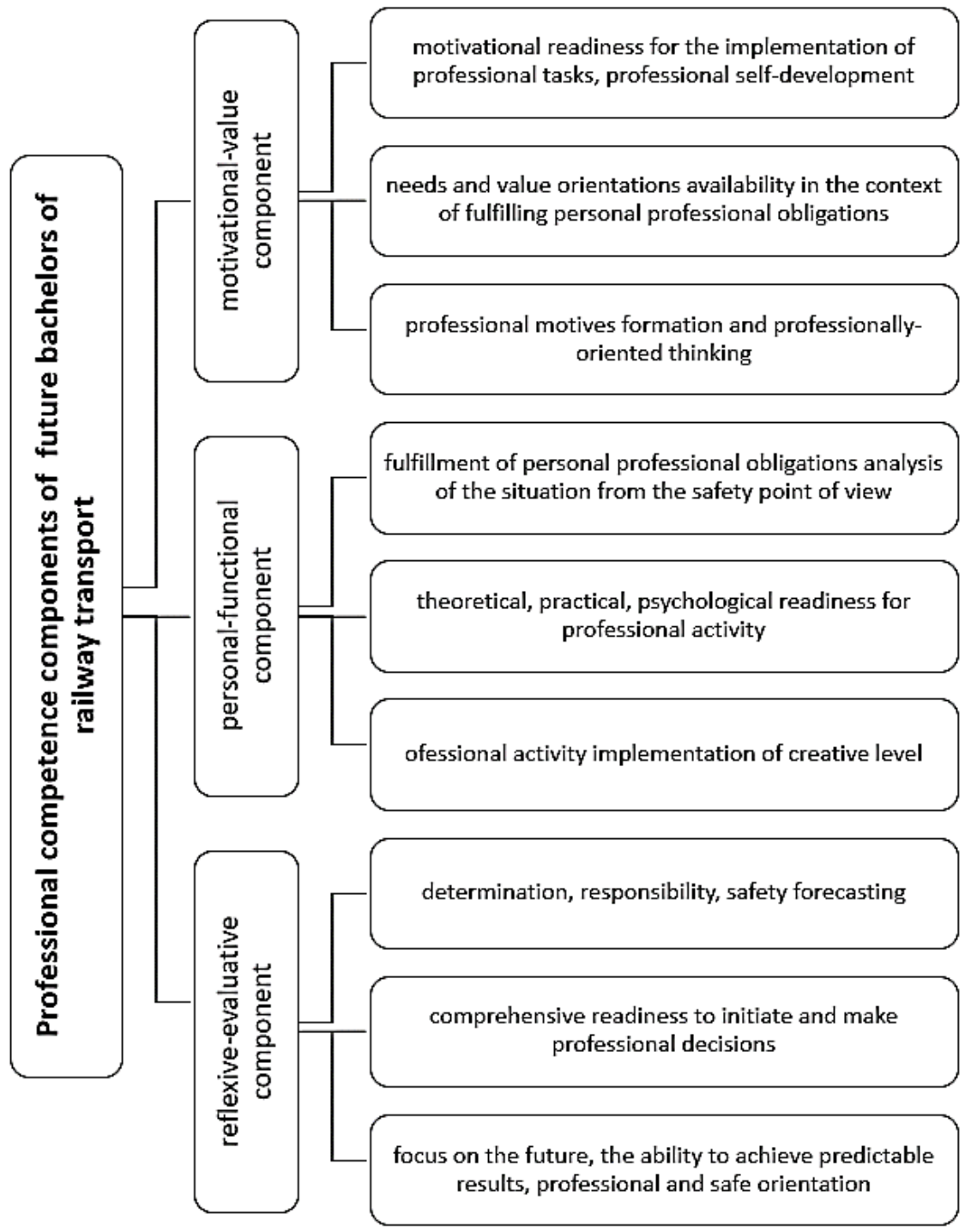

Fig. 1. The professional competence structure of future bachelors of railway transport 
- motivational-value (motivational readiness for the implementation of professional tasks, professional selfdevelopment; the presence of need-value orientations in the context of personal professional obligations; the formation of professional motives and professional-oriented thinking, etc.);

- personal-functional (theoretical, practical, psychological readiness for professional activity; fulfillment of personal professional obligations; analysis of the situation from the point of view of safety; realization of professional activity of creative level, etc.);

- reflexive-evaluative (determination, responsibility, safety forecasting; comprehensive readiness to initiate and make professional decisions; focus on the future, the ability to achieve predictable results, professional and safe orientation, etc.).

The selected components should be considered in more detail. Motivational-value component is manifested in the awareness formation of the need for professional self-development, motivational readiness to solve production problems, creating motivationally favorable conditions; conducting motivational activities, educational and training direction; mastering the concepts system for the railway transport bachelors organization and safe production environment creation, the regulations operation of the industry; the presence of motivational and value orientations in unity with the desire for professional activity, in the desire to form professional motives, as well as professionally-oriented thinking. The future specialists' direct participation (in particular, together with practicing professionals) in activities of a professional nature (forums, scientific and practical conferences, thematic seminars, electives, etc.) contributes to the formation of this component.

Personal-functional component includes the ability to make management decisions in the professional needs presence and to defend personal professional views; skills formation for the measures implementation that contribute to the professional competence formation of higher education and provide professional guidance in the course of professional activity; personal qualities formation (determination, responsibility, initiative, willingness to take risks, etc.). This professional competence component of future bachelors of railway transport in professional training is related to the readiness and ability of the specialist to organize professional tasks at the appropriate level, labor protection advocacy, their own self-educational activities modeling in this area, preparedness for various professional activities, work planning technologies, labor discipline observance, events organization that promote the implementation of professional tasks of the creative level, injuries and accidents prevention at enterprises, non-compliance causes analysis with labor protection requirements, etc.

The reflective and evaluative component provides a combination of skills to critically assess the professional resources quality, analyzing the conditions and circumstances of production tasks; ability to self-assess one's own level of professional competence; tendency to plan one's own trajectory of professional growth and increase the level of readiness for selfdevelopment and self-improvement; personal and professional reflection ability, actions and management decisions self-analysis in solving production problems; the need to organize self-understanding of the obtained intermediate or final results; positive motives of conscious reflexive activity; tendency to personal interest in assessing one's own reflection; the manifestation level of self-importance and self-esteem; providing a creative approach to solving issues of a production nature; internal activity selfcontrol; desire to grow professionalism; value-semantic attitude to professional reflection.

\section{DISCUSSION}

DeSeCo experts define the competence (competency) concept as the ability to successfully satisfy individual and social needs, act and perform tasks. Every competence built on a combination of mutually corresponding cognitive attitudes and practical skills, values, emotions, behavioral components, knowledge and skills, all that can be mobilized for actions.

According to research by British psychologist J. Raven, represented in the works "Competence in modern society" (Raven, 2002), competence is a specific ability, which is required to effectively perform a specific action in a specific subject area, covering professional knowledge, subject skills, methods thinking, as well as understanding the responsibility for their actions.

Professional competence allows a specialist to perform successfully various types of professional activities, it synthesizes a wide range knowledge and practical actions, reflects the degree of formation of specialist's professional culture (Ruchen, Dominique, 2003). Professional competence is the measure and the main criterion professional training and ability of the labor subject to perform tasks and responsibilities in accordance with the position he holds. At the same time professional competence is seen as an integrative quality, an ability that cannot be limited only by the presence of a certain amount of knowledge, skills and abilities. Mostly it presupposes such personal qualities that provide an opportunity to find and select the necessary knowledge, mode of action in a given situation.

Hutmacher (1996) during a presentation at a symposium in Bern proposed its own list of competencies that are common to all professions and specialties, namely: "competences related to life in multicultural society: perception of differences, respect for others, tolerance for other cultures, languages and religions; competencies related to society informatization, the ability to critically evaluate the information disseminated by the media and advertising, obtain relevant information; implementing competencies ability and desire for lifelong learning as a condition to maintain professionalcompetitiveness".

Ovcharuk (2004) on the basis of the analysis of foreign experience, gives the list the following key competencies: "informational; socio-psychological; civil; communicative; methodological; vital; professional; psychological (reflexive). The main key competencies components: a set of knowledge, skills, abilities, relationships, values, attitudes and others factors that constitute personal and social aspects of man's life and work and on whom personal and social progress depends"(Ovcharuk, 2004, 49).

The professional training of future bachelors of railway transport should be reoriented both to the requirements of society and the state, and, of course, to the employer's requirements. The educational process level in higher education must meet todays requirements and challenges. Of course, quality training is the basis for the society and infrastructure development progress, a guarantee of competitiveness and career growth of the future specialist. "In the new socio-economic conditions of the labor market, society and employers make higher demands on the training quality of different levels specialists, who not only should have the necessary knowledge in their professional field, but also have the skills to apply them in solving production problems. the first days of independent professional activity" (Prigodiy, 2010). 
In our opinion, the professional competence structure should be tight related to the content of the specialist's qualification description. The competencies division is directed, but due to relationship between them, we decided to create universal components of professional competence of future bachelors' professional training of railway transport.

It is well known that a specialist is a person who, after appropriate training, has the necessary level of special knowledge and skills in a particular field. Before recognizing one's own ability as a specialist, the future specialist must understand their own professional development feasibility, the process of acquiring new competencies, knowledge, skills and abilities that he will use in professional activities. Professional development is the employees' training, retraining and advanced training in order to form readiness to perform new production tasks and responsibilities of other positions. It should be noted that professional competence is this process integral part. It is well known that a specialist is one who is well versed in a profession.

In the competence approach conditions it is impossible to stop only on knowledge, skills and studying abilities. The Law of Ukraine "On Education" defines competence as "a dynamic combination of knowledge, skills, abilities, ways of thinking, views, values, other personal qualities, which determines a person's ability to successfully socialize, conduct professional and / or further educational activities" (Law of Ukraine "On Education"). The Law of Ukraine "On Higher Education" - as a dynamic combination of knowledge, skills and practical skills, ways of thinking, professional, ideological and civic qualities, moral and ethical values, which determines a person's ability to successfully carry out professional and further educational activities and is the result of education at a certain level of higher education" (Law of Ukraine "On Higher Education"); in the National Qualifications Framework - as "the person's ability to perform a certain activity type, which is expressed through knowledge, understanding, skills, values, other personal qualities" (National Qualifications Framework).

Professional training of future bachelors of railway transport is a systemic purposeful activity that covers the formation of both general scientific knowledge, and narrowly professional, both a broad scientific worldview and a number of values and qualitative traits.

Updating the flow of information and scientific and technological progress dictate the following requirements to future railway transport bachelors: ability to overcome contradictions in learning and professional activity, the desire to improve the professional field, mastery of innovations and willingness to implement them in professional activity. For the successful implementation of professional activities, future professionals must have a number of qualities: the ability to generalize knowledge and use their synthesis in non-standard situations, ability to work in a team and leadership qualities, sufficient professional knowledge to start a professional career, the desire for self-improvement, improving their professional level.

Professional competence is formed in activity, it is not static, but can develop and acquire higher formation levels. Professional competence can be seen as a unity of professional competences that are formed in students by involving them in active educational and cognitive activities. Scientists O. Pometun and A. Khutorskaya distinguish the following hierarchical levels in their competencies: subject, general subject, interdisciplinary, supersubject (Pometun, 2005).

Therefore, the professional competence of the future bachelors of railway transport is his willingness and ability to use in his professional competencies in professional activity. Formation of professional competence in future bachelors of railway transport is a system of coordinated actions of teachers of the educational institution (college, university) aimed at creating an educational environment in which applicants will develop skills, abilities and experience, the acquisition of key personality traits necessary for the successful implementation of professional activities. This formation does not end together with graduation from college or university, and lasts a lifetime (training, professional growth, etc.)

The following components: motivational - as a willingness to show competence; cognitive - knowledge of the competence content; behavioral - the competence experience in various standard and non-standard situations; value-content attitude to the competence content and its application object; emotional and volitional process regulation and result of the competence manifestation were distinguished by I. Zymnya in the competence structure (Zymnya, 2008, p. 52).

While professional competence formating of future bachelors of railway transport in the higher education process, it should be noted that an important factor in this process success and effectiveness is the interest in improving the formation level of this quality by a particular person. Highlighted, that it is important for future engineers to have comprehensive professional knowledge and innovations in the work organization. It is established that the professional competence formation of future bachelors is an important component in their professional training structure.

\section{CONCLUSIONS AND PROSPECTS OF FURTHER RESEARCH}

Thus, determining the professional competence structure of future bachelors of railway transport (motivational-value, personal-functional, reflexive-evaluative) will provide a clearer planning of this competence process formation. Understanding each component content of professional competence of future professionals will ensure the professionally-oriented technologies use for the professional competence formation in its components. The further scientific research subject will be related to the development of this process model and its organizational and methodological support.

\section{References}

1. Chaplak, M., Kotova, S. (2010). Modern trends in the professional competence formation of future teachers. Modern issues of world science.

2. Gorban, S.I. (2015). Specialists' professional competence: essence and structure. Pedagogy of creative personality formation in higher and general education schools. 45 (98). P.87-93.

3. Hutmacher, W. (1996). Key competencies for Europe. Report of the Symposium in Berne, Switzerland. Council for Cultural Cooperation. Secondary Education for Europe. Strasburg, France

4. Karpova, L.G. (2004). Formation of the secondary school teacher professional competence: Author's abstract. dis. ... Ph.D. Kharkiv: KhDPU named after GS Skovorodi.

5. Kovalenko, O.E. (2007). Professional and pedagogical training of the future engineer teacher. Theoretical and methodological principles of pedagogical education: pedagogical skills, creativity, technology. 115-120. 
6. Kremen, V.G. (2008). Encyclopedia of Education.

7. Law of Ukraine "On Education". Retrieved from: http://zakon2.rada.gov.ua/laws/show/2145-19.

8. Law of Ukraine "On Higher Education". Retrieved from: http://zakon3.rada.gov.ua/laws/show/1556-18.

9. Lytvyn, V., Andrushchenko, V., Gurzhiy, A. (2004). Scientific and educational potential of the nation: a view in the XXI century. K.: Education and science: the creative potential of state and cultural creation.

10. National Qualifications Framework. Retrieved from: http://zakon4.rada.gov.ua/laws/show/1341-2011-p.

11. Nizovtsev, A.V. (2013). Development of an engineer's professional competence model. Pedagogical sciences: theory, history, innovative technologies. 8 (34). 243-255.

12. Omelchenko, L.M., Kernytsky, O.M. (2010). The problem of professional competence formation of future specialists of energy profile in modern conditions. Bulletin of Kremenchug State University named after Mykhailo Ostrogradsky. Kremenchuk: KSU. Vip. 3 (62), Part 1. P. 169-172.

13. Ovcharuk, O.V. (2004). Competence approach in modern education: world experience and Ukrainian perspectives.

14. Pometun, O.I. (2005). Civic competence formation: a view from the standpoint of modern pedagogical science. Bulletin of school exchange programs. 23. 18-20.

15. Prigodiy, M., Vasyuchenko, P. (2010). Professiogram of the practical training teacher in the electric power field as the basis of the electrical competence formation system. Problems of modern pedagogical education: pedagogy and psychology. 28. Part 1. 147-155.

16. Raven John. (2002). Competence in modern society: identifying, development and realization.

17. Skibina, O.V. (2012). The essence and structure of professional competence of future engineers-teachers. Spirituality of personality: methodology, theory and practice. 1 (48). 150-157.

18. Standard of higher education of the first (bachelor's) level of specialty 273 - Railway transport. Ministry of Education and Science of Ukraine. Kyiv. 2018. 20 p.

19. Vyshpolska, V.F. (2008). Content and structure of a specialist's professional competence in international economic relations. Visnyk of Zaporizhzhya National University. 1. 57-61.

20. Yevtushenko, G.I., Vitrenko, L.O. (2013). Ways of forming the professional competence of the future manager. Collection of scientific works of the National University of State Tax Service of Ukraine. 1. P. 69-78.

21. Zimnya, I.A. (2008). Unified social and professional competence of a university graduate: the concept, approaches to the formation and evaluation: handouts for classes. Retrieved from: misis.ru/Portals/0/Download/Press/2011

\section{СТРУКТУРА ПРОФЕСІЙНОЇ КОМПЕТЕНТНОСТІ МАЙБУТНІХ БАКАЛАВРІВ ЗАЛІЗНИЧНОГО ТРАНСПОРТУ У ФАХОВІЙ ПІДГОТОВЦІ \\ А.О. Гребеник}

Глухівський національний педагогічний університет імені Олександра Довженка, Україна

Анотація. За інтенсивних умов життя і виробництва все частіше виникають питання не стільки про зміст засвоєних студентами знань, скільки про високоефективні методи, форми, засоби формування професійної компетентності як вагомого складника фахової підготовки. На основі аналізу науково-педагогічної літератури автором виокремлено структурні компоненти професійної компетентності майбутніх бакалаврів залізничного транспорту. у даній статті порушено проблему формування професійної компетентності майбутніх фахівців залізничної галузі у фаховій підготовці.

Формулювання проблеми. Нині все частіше роботодавці не в повній мірі задоволені підготовкою фахівців. Як наслідок, відбувається суттєве реформування освітньої галузі. Питанням фахової підготовки приділяється особлива увага. Отже, формування професійної компетентності майбутнього фахівця $\epsilon$ актуальним і значимим питанням. А питання структури професійної компетентності майбутніх фрахівців, у тому числі й майбутніх бакалаврів залізничного транспорту, потребує детального вивчення. Даному питанню й присвячено дану статтю.

Матеріали і методи. У процесі написання статті застосовувались матеріали дисертаційних досліджень, педагогічної та наукової літератури. Для досягнення поставленої мети дослідження використовувалися теоретичні й емпіричні методи: аналіз і систематизація; спостереження; письмове та усне опитування; аналіз, систематизація, узагальнення.

Результати. Таким чином, у процесі проведення даного дослідження визначено компоненти професійної компетентності майбутніх бакалаврів залізничного транспорту, а саме: мотиваційно-ціннісний, особистісно-функціональний, рефлексивнооцінювальний.

Висновки. Запропонована структура професійної компетентності майбутніх бакалаврів залізничного транспорту сприяє формуванню ефективного освітнього середовища в закладах вищої школи щодо фахової підготовки майбутніх бакалаврів, дає можливість використання сучасних професійно-орієнтованих технологій для досягнення більш високого рівня сформованості професійної компетентності по кожному їі складнику. Подальшого дослідження потребують питання щодо розробки моделі зазначеного процесу та організаційно -методичного ії забезпечення.

Ключові слова: фахова підготовка, професійна компетентність, компоненти, бакалавр залізничного транспорту, професіонал.

\section{$(\mathrm{Cc}) \mathrm{BY}-\mathrm{NC}-\mathrm{SA}$}

This work is licensed under Creative Commons Attribution-NonCommercial-ShareAlike 4.0 International License. 